\title{
PERKEMBANGAN KOGNITIF PADA PESERTA DIDIK SMP (Sekolah Menengah Pertama) MENURUT JEAN PIAGET
}

\author{
Annisa Mauliya \\ Program Studi Pendidikan IPA, Fakultas Keguruan dan Ilmu Pendidikan Universitas Jember
}

\begin{abstract}
The cognitive word comes from the word cognition which has the reliability of the word to know (know). This article aims to find out how the basic concepts of cognitive development in junior high school children (junior high school) according to Jean Piaget. The type of research used is library research. This study focuses on cognitive concepts that occur in children according to Jean Piaget. The implication of Jean Piaget's theory in the process is to help educators to understand the cognitive processes and activities of the participants to help determine the cognitive level of students and choose learning strategies that are in line with the developmental failures of the students.
\end{abstract}

Keywords: cognitive, process, learning strategies

\section{PENDAHULUAN}

Jean Piaget lahir pada tahun 1989 di Neuhatel, Swiss. Ayahnya adalah seorang profesor spesialis ahli sejarah abad pertengahan, sedangkan ibunya adalah seorang yang dinamis, inteligen dan takwa. Perkembangan dari pemikiran Piaget lebih dipengaruhi oleh Samuel Cornut, yaitu bapak pelindungnya, seorang ahli dari Swiss. Cornut mengamati bahwa Piaget, pada masa remajanya terlalu memusatkan pikirannya pada biologi. Menurutnya, hal tersebut bisa membuat pikiran Piaget kurang luas. Karenanya, Cornut ingin mempengaruhi Piaget yaitu dengan memperkenalkan filsafat. Semua itu membuat Piaget mulai tertarik pada bidang epistimologi yang merupakan suatu cabang filsafat tentang mempelajari pengetahuan, apa itu pengetahuan dan bagaimana pengetahuan itu diperoleh. Dalam dekade hidup Piaget hingga akhir masanya, ia telah menulis lebih dari 60 buku dan ratusan artikel. Jean Piaget meninggal di Genewa pada tangggal 16 September 1980. Ia menjadi salah satu tokoh psikologi penting pada abad ke-20. (Ibda, 2015:27-28).

Secara psikologis, menurut Piaget, masa remaja adalah masa dimana individu bersinergi dengan masyarakat dewasa, dimana anak tidak lagi merasa di bawah level orang dewasa tetapi dalam tingkatan yang sama, setidaknya dalam masalah hak. Peserta didik yang berada pada masa remaja merupakan individu-individu yang sedang dalam proses pencarian identitas menuju dewasa. Perkembangan menuju kedewasaan memerlukan perhatian dari para pendidik secara sungguh-sungguh dan diperlukan pendekatan psikologis-pedagogis serta pendekatan sosiologis terhadap perkembangan remaja, guna memperoleh data yang objektif tentang masalah-masalah yang dihadapi. (Khiyarusoleh, 2016:2).

Dalam pandangan Jean Piaget, belajar yang sebenarnya bukan sesuatu yang di ajarkan oleh guru, namun sesuatu yang berasal dari dalam diri anak itu sendiri. Belajar merupakan sebuah proses penyelidikan dan penemuan spontan. Setidaknya terdapat tiga ranah yang harus dikembangkan melalui proses pendidikan secara seimbang, salah satunya mengikuti pendapat Bloom yang membaginya menjadi tiga ranah perkembangan perilaku individu antara lain: a) cognitive domain, $b$ ) affective domain, c) psychomotor domain. (Khiyarusoleh, 2016:3).

Tahapan Piaget mengenai perkembangan intelektual adalah: Pertama Sensorimotor (sejak kelahiran s/d usia 2 tahun), yaitu membedakan diri sendiri dengan setiap objek. Mengenal diri sebagai pelaku kegiatan dan mulai bertindak dengan tujuan tertentu. Menguasai keadaan tetap dari objek atau menyadari bahwa benda 
tetap ada meskipun tidak lagi terjangkau oleh indra. Kedua, Praoperasional (2-7 tahun), yaitu belajar menggunakan bahasa dan menggambarkan objek dengan imajinasi dan kata-kata. Berpikir masih bersifat egosentris, atau mempunyai kesulitan menerima pandangan orang lain. Mengklasifikasikan objek menurut satu tanda. Ketiga, Operasional/konkret (7-12 tahun), yaitu mampu berpikir logis mengenai objek dan kejadian. Menguasai konservasi jumlah, jumlah tak terbatas, dan berat. Mengklasifikasikan objek menurut beberapa tanda dan mampu menyusunnya dalam satu seri berdasarka satu dimensi, seperti ukuran. Keempat, operasional formal (12 tahun ke atas), yaitu mampu berpikir logis mengenai soal abstrak serta menguji hipotesis secara sistematis. Menaruh perhatian terhadap masalah hipotesis, masa depan, dan masalah ideologis. (Mukhlisah, 2015:119-120).

Tujuan dari artikel ini ialah untuk mengetahui dengan jelas dan terinci bagaimana konsep dasar dari teori pembelajaran oleh Jean Peaget ini. Dimana, anak SMP adalah seorang remaja yang masih mengalami perkembangan, baik fisik maupun psikologis. Jadi, dengan mengerti konsep dasar dari Jean Peaget ini, para pendidik dapat lebih mawas diri dalam menyampaikan sesuatu, baik itu pelajaran maupun pencontohan perilaku. Pendidik dapat lebih menerima sifat dan karakter berbeda dari peserta didiknya dengan bijaksana. Supaya nantinya akan berkembang peserta didik yang memiliki perilaku teladan dan dapat bersosial dengan masyarakat.

\section{METODE PENELITIAN}

Jenis penelitian ini adalah penelitian kepustakaan atau studi pustaka (library research). Karena peneliti memanfaatkan sumber pustaka untuk memperdalam kajian teoretis atau mempertajam metodologi juga memanfaatkan sumber pustaka untuk memperoleh jawaban atas masalah yang ditanya-tanyakan.

\section{HASIL DAN PEMBAHASAN}

\section{A. Pengertian Perkembangan Kognitif}

Kognitif berasal dari kata cognition yang memiliki persamaaan kata dengan knowing (mengetahui). Berdasarkan dasar teori yang dibangun oleh Piaget, beberapa penulis mendefinisikan kognisi dengan penuturan yang berbeda-beda, namun pada dasarnya sama, yaitu aktivitas mental dalam mengenal dan mengetahui tentang dunia. Kognisi didefinisikan sebagai proses berpikir dimana informasi dari pancaindera diubah, direduksi, dielaborasi, diperbaiki, dan digunakan. Istilah kognitif menurut Chaplin adalah salah satu wilayah atau domain/ranah psikologis manusia yang meliputi perilaku mental yang berhubungan dengan pemahaman, pertimbangan, pengolahan informasi, pemecahan masalah, kesengajaan, dan keyakinan. Ranah kognitif juga memiliki hubungan dengan kehendak dan perasaan yang berkaitan dengan wilayah rasa. Menurut Santrock, kognisi mengacu kepada aktivitas mental tentang bagaimana informasi bisa masuk ke dalam pikiran, disimpan dan diubah, serta dipanggil kembali dan digunakan dalam aktivitas kompleks seperti berpikir. Dari beberapa definisi di atas dapat dipahami bahwa kognisi merupakan salah satu aspek perkembangan individu yang meliputi kemampuan dan aktivitas mental yang berkaitan dengan proses penerimaanpemrosesan-dan penggunaan informasi dalam bentuk berpikir, pemecahan masalah, dan adaptasi. (Khiyarusoleh, 2016:4-5).

\section{B. Tahap-Tahap di dalam Teori Peaget}

Bagi Piaget (Mukhlisah, 2105:119), proses belajar berlangsung dalam tiga tahapan yakni: Asimilasi, Akomodasi dan Equilibrasi. Kompleksnya pengetahuan dan struktur kognitif tidak dengan sendirinya menyebabkan terjadinya asimiliasi secara lancar. Dalam kasus tertentu asimilasi mungkin saja tidak terjadi karena informasi baru yang diperoleh tidak sesuai dengan stuktur kognitif yang ada. Dalam konteks seperti ini, struktur kongitif perlu disesuaikan dengan pengetahuan baru yang diterima. Proses semacam ini disebut 
akomodasi. Penekanan Piaget tentang betapa pentingnya fungsi kognitif dalam belajar didasarkan pada tahap perkembangan kognitif manusia. Menurut Sitti Aisyah (2013:91), asimilasi dan akomodasi adalah dua bentuk adaptasi, diamana merupakan istilah Piaget yag disebut dengan pembelajaran. Cara kerja asimilasi dan akomodasi yaitu bertugas menyeimbangkan struktur pikiran dengan lingkungan dan menciptakan porsi yang sama di antara keduanya. Jika keseimbangan ini terjadi, maka terciptalah suatu keadaan ideal atau equiblirium. Menurut Anatri Desstya (2014:196), asimilasi merupakan proses penyatuan atau pengintegrasian informasi baru ke dalam struktur kognitif yang telah dimiliki. Akomodasi merupakan proses penyesuaian struktur kognitif ke dalam situasi yang baru. Ekuilibrasi merupakan proses penyesuaian yang berkesinambungan antara asimilasi dan akomodasi. Apabila dengan asimilasi seseorang tidak dapat mengadakan adaptasi dengan lingkungannya, maka akan terjadi ketidakseimbangan (diliquibrasi). Jadi, seseorang yang mengalami equilibrasi akan mengalami perubahan intelektual yang lebih tinggi.

Menurut Mukhlisah (2015:119-120), tahapan Piaget mengenai perkembangan intelektual adalah: Pertama Sensorimotor (sejak kelahiran s/d usia 2 tahun). Kedua, Praoperasional (2-7 tahun). Ketiga, Operasional/konkret (7-12 tahun). Keempat, operasional formal (12 tahun ke atas). Menurut Sitti Aisyah (2013:92), dalam tahap sensorimotor, bayi menyusun pemahaman dunia dengan mengoordinasikan pengalaman indra (sensory) mereka dengan gerakan motor (otot). Pada awal tahap ini, bayi memperlihatkan tak lebih dari pola reflektif untuk beradaptasi dengan dunia. Di usia antara satu sampai empat bulan, seorang bayi mengandalkan reaksi sirkular primer, yaitu tindakan atau gerakan yang dia buat sebagai respons dari tindakan sebelumnya dengan bentuk yang sama. Di usia empat sampai dua belas bulan, bayi beralih pada reaksi sirkular sekunder yang berisi tindakan-tindakan yang berusaha terlibat dengan lingkungan sekitar. Dia berusaha mempelajari "prosedur dan cara kerja" sesuatu yang dapat menyenangkan hatinya dan mengusahakannya agar terus bertahan. Dengan cara ini, dia mulai belajar mengingat objek secara permanen. Ini adalah kemampuan untuk mengingat, artinya kalau anda tidak dapat melihat sesuatu, bukan berarti sesuatu itu hilang. Di usia dua belas sampai dua puluh empat bulan, anak-anak menggunakan reaksi sirkular tersier, yatiu mempertahankan halhal yang menarik, akan tetapi dengan variasi yang lebih tetap. Ketka seorang bayi berusia satu setengah tahun, bayi tersebut mengalami perkembangan representasi mental, yaitu kemampuan mempertahankan citraan dalam pikirannya untuk jangka waktu yang lebih lama. Menjelang akhir tahap ini, bayi menunjukkan pola sensorimotor yang lebih kompleks. Piaget percaya bahwa pencapaian kognitif yang penting di usia bayi adalah object permanence, yang berarti bahwa pemahaman objek dan kejadian terus eksis bahkan ketika objek dan kejadian itu tidak dapat dilihat, didengar atau disentuh. Pencapaian kedua adalah realisasi bertahap, bahwa ada perbedaan atau batas antara diri dan lingkungan sekitar. Menjelang akhir periode sensorimotor, anak bisa membedakan antara dirinya dan dunia sekitarnya dan menyadari bahwa objek tetap ada dari waktu ke waktu.

Tahap pra-operasional adalah tahap pemikiran yang lebih simbolis, tetapi tidak melibatkan pemikiran operasional. Tahap ini lebih bersifat egosentris dan intuitis. Pemikiran pra-operasional terdiri dari dua subtahap, yaitu tahap fungsi simbolis dan tahap pemikiran intuitif. Sub-tahap fungsi simbolis terjadi di usia dua sampai empat tahun. Dalam sub tahap ini, anak kecil secara mental mulai mempresentasikan objek yang tidak hadir. Ini memperluas dunia mental anak hingga mencakup dimensi-dimensi baru. Perkembangan bahasa yang mulai berkembang dan kemunculan sikap bermain adalah contoh dari peningkatan pemikiran fungsi simbolis. Anak kecil mulai mencoret-coret gambar orang, rumah, mobil, awan dan bendabenda lain di dunia ini. Dalam imajinasi mereka, matahari warnanya biru, langit 
berwarna hijau dan mobil melayang di awan. Simbolisme yang sederhana tetapi kuat, tidak berbeda dengan lukisan abstrak. Di usia Sekolah Dasar, lukisan anak menjadi makin realitas, rapi dan persis. Matahari berwarna kuning, langit berwarna biru dan mobil berada di jalanan. Pemikiran pra-opersional masih mengandung dua keterbatasan, yaitu egosentrisme dan animisme. Egosentrisme adalah ketidakmampuan untuk membedakan antara perspektif milik sendiri dengan perspektif orang lain. Piaget dan Barber Inhelder mempelajari egosentrisme anak dengan memberikan tugas gunung. Animisme juga merupakan ciri pemikiran pra-operasional. Animisme adalah kepercayaan bahwa objek tidak bernyawa punya kualitas "kehidupan" dan bisa bergerak. Seorang anak kecil menunjukkan animisme ini dengan mengatakan "pohon itu mendorong daun dan membuatnya gugur" atau "trotoar itu membuatku terjatuh".

Dalam tahap pra-opersional juga menunjukkan karakteristik pemikiran yang disebut centration yakni pemfokusan (pemusatan) perhatian pada satu karakteristik dengan mengabaikan karakteristik lainnya. Centration tampak jelas dalam kurangnya konservasi dalam tahap ini. Konservasi yang dimaksud di sini adalah ide bahwa beberapa karakteristik dari objek itu tetap sama meski objek itu berubah penampilannya. Misalnya, orang dewasa tahu bahwa volume air akan tetap sama meskipun dia dimasukkan ke dalam wadah yang bentuknya berlainan. Tetapi bagi anak kecil tidak demikan halnya. Mereka biasanya heran pada perubahan bentuk cairan di dalam wadah yang berbeda-beda.

Tahap opersional konkret, dimulai umur tujuh tahun sampai sebelas tahun. Pemikiran operasional konkret mencakup penggunaan operasi. Penalaran logika menggantikan penalaran intuitif, tetapi hanya dalam situasi konkret. Kemampuan untuk mengklasifikasikan sesuatu sudah ada, tetapi belum bisa memecahkan problem-problem abstrak. Operasi konkret adalah tindakan mental yang bisa dibalikkan yang berkaitan dengan objek konkret nyata. Tahap ini dimulai dengan tahap progressive decentring di usia tujuh tahun. Sebagian besar anak telah memiliki kemampuan untuk mempertahankan ingatan tentang ukuran, panjang atau jumlah benda cair. Maksud ingatan yang dipertahankan di sini adalah gagasan bahwa satu kuantitas akan tetap sama walaupun penampakan luarnya terlihat berubah. Anak usia sekolah dasar berada pada tahap operasional konkret. Pada tahap ini, anak masih sangat membutuhkan benda-benda konkret untuk membantu pengembangan kemampuan intelektualnya. Pada akhir tahap operasional konkret, mereka telah dapat memahami tentang perkalian, menulis dan berkorespondensi, dan mulai dapat berpikir abstrak yang sederhana, misalnya memahami konsep berat, gaya, dan ruang. Anak mulai memecahkan masalah khusus, mempelajari keterampilan, dan kecakapan berpikir logis yang membantu mereka memaknai pengalaman. Tahap ini merupakan perkembangan dari tahap praoperasional yang dimulai dengan proses internalisasi melalui pancaindra sampai ke otak.

\section{Tingkatan Perkembangan Intelektual - Kedewasaan}

Perkembangan sistem saraf sentral yaitu otak, koordinasi motorik dan manifestasi fisik lainnya menpengaruhi perkembangan kognitif. Kedewasaan atau maturasi merupakan faktor penting dalam perkembangan intektual.

\section{- Penalaran Moral}

Bila seorang anak menjatuhkan sebuah benda dan menemukan bahwa benda itu pecah atau bila ia menempatkan benda itu dalam air, kemudian ia melihat bahwa benda itu terapung ia sudah terlibat dalam proses abstraksi sederhana atau abstraksi empiris. Pengalaman ini disebut pengalaman fisik untuk membedakannya dengan pengalaman logika-matematika, tetapi secara paradoks pengalaman fisik ini selalu melibatkan asimilasi pada strukturstruktur logika-matematika. Pengalaman fisik ini meningkatkan kecepatan perkembangan anak sebab observasi benda- 
benda serta sifat-sifat benda itu menolong timbulnya pikiran yang lebih kompleks.

\section{- Pengalaman Logika-Matematika}

Pengalaman yang dibangun oleh anak, yaitu ia membangun atau menkonstruks hubungan-hubungan antara objek-objek. Sebagai contoh misalnya, anak yang sedang menghitung beberapa kelereng yang dimilikinya dan ia menemukan "sepuluh" kelereng. Konsep "sepuluh" bukannya sifat kelereng-kelereng itu, melainkan suatu kontruksi lain yang serupa, yang disebut pengalaman logika-matematika.

\section{- Transmisi Sosial}

Dalam tansmisi sosial, pengetahuan itu datang dari orang lain, seperti pengaruh bahasa, instruksi formal dan membaca, begitu pula interaksi dengan teman-teman dan orang-orang dewasa termasuk faktor transmisi sosial dan memegang peranan dalam perkembangan.

\section{- Pengaturan Sendiri}

Pengaturan sendiri atau ekuilibrasi adalah kemampuan untuk mencapai kembali keseimbangan (equilibrium) selama periode ketidakseimbangan (disequlibrium). Ekuilibrasi merupakan suatu proses untuk mencapai tingkat-tingkat berfungsi kognitif yang lebih tinggi melalui asimilasi dan akomodasi tingkat demi tingkat.

\section{Penerapan Teori Kognitif Jean Piaget pada Peserta Didik SMP}

Di Indonesia individu yang memasuki tahap operasi formal terjadi pada usia remaja yakni pada usia sekolah menegah (SMP dan SMA). Namun berdasarkan pengalaman peneliti (Aini, dkk, 2017:26), sebagian besar siswa SMP kesulitan pada saat mempelajari materi ajar matematika. Banyak sekali faktor yang mempengaruhi hal tersebut. Salah satunya dikarenakan karakteristik materi ajar matematika yang bersifat abstrak. Selain itu dimungkinkan bahwa siswa SMP masih belum memasuki tahap operasi formal. Meskipun berdasarkan tahapan Piaget, berdasarkan usia, pada usia SMP seharusnya siswa sudah memasuki tahap operasi formal. Seperti yang dikatakan Russefendi bahwa masih terdapat peserta didik yang telah lulus di jenjang sekolah menengah dan juga mahasiswa tidak pernah mencapai tahap penalaran formal.

\section{SIMPULAN}

Secara psikologis, menurut Piaget, masa remaja adalah masa dimana individu bersinergi dengan masyarakat dewasa, dimana anak tidak lagi merasa di bawah level orang dewasa tetapi dalam tingkatan yang sama, setidaknya dalam masalah hak. Peserta didik SMP memasuki tahap operasi formal. Meskipun berdasarkan tahapan Piaget, berdasarkan usia, pada usia SMP seharusnya siswa sudah memasuki tahap operasi formal. Dikarenakan terdapat peserta didik yang telah lulus di jenjang sekolah menengah dan juga mahasiswa tidak pernah mencapai tahap penalaran formal.

\section{DAFTAR PUSTAKA}

Aina, Indrie Noor dan Hidayati, Nita. 2017. Tahap Perkembangan Kognitif Matematika Siswa Smp Kelas Vii Berdasarkan Teori Piaget Ditinjau Dari Perbedaan Jenis Kelamin. JPPM. Vol.10(2):25-30.

AM, Mukhlisah. 2015. Pengembangan Kognitif Jean Piaget Dan Peningkatan Belajar Anak Diskalkulia (Studi Kasus Pada Mi Pangeran Dipenogoro Surabaya). Jurnal Kependidikan Islam. Vol.6(2):118-143.

Desstya, Anatri. 2014. Kedudukan Dan Aplikasi Pendidikan Sains Di Sekolah Dasar. Profesi Pendidikan Dasar. Vol.1(2):193-200.

Ibda, Fatimah. 2015. Perkembangan Kognitif: Teori Jean Piaget. Intelektualita. Vol. 3(1):27-38.

Khiyarusoleh, Ujang. 2016. Konsep Dasar Perkembangan Kognitif Pada Anak Menurut Jean Piaget. Jurnal Dialektika Jurusan PGSD. Vol.5(1):1-10. 
Mu'min, Sitti Aisyah. 2013. Teori

Jurnal $\quad$ Al-Ta'dib.Vol.6(1):89-99

Perkembangan Kognitif Jean Piaget. 